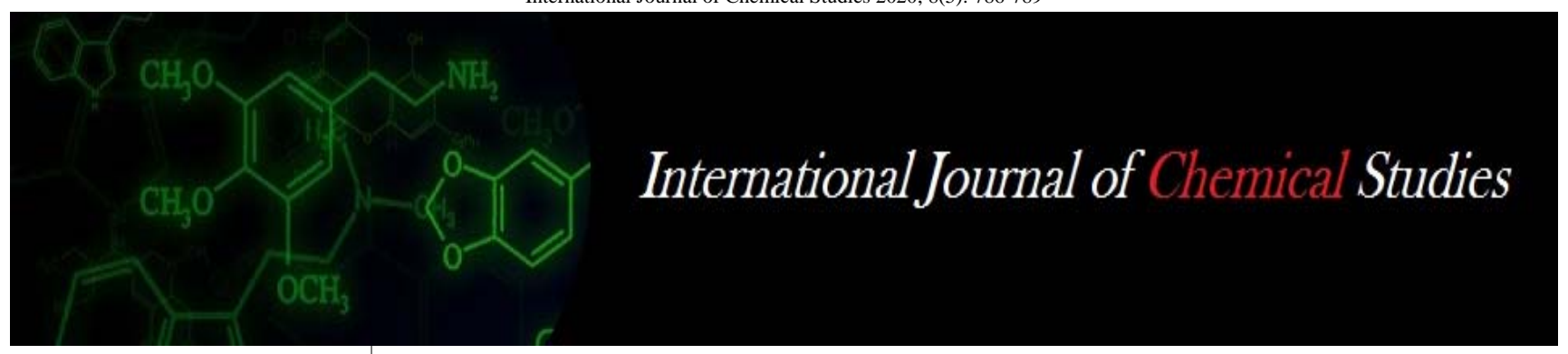

P-ISSN: 2349-8528 E-ISSN: 2321-4902 www.chemijournal.com IJCS 2020; 8(5): 786-789 (C) 2020 IJCS

Received: 06-07-2020 Accepted: 21-08-2020

Saumi Goswami Department of Agronomy, Faculty of Agriculture Bidhan Chandra Krishi Viswavidyalaya, PO - Krishi Viswavidyalaya, Mohanpur, Nadia, West Bengal, India

Champak Kumar Kundu Department of Agronomy, Faculty of Agriculture Bidhan Chandra Krishi Viswavidyalaya, PO - Krishi Viswavidyalaya, Mohanpur, Nadia, West Bengal, India

Soumyajyoti Das Department of Agronomy, Faculty of Agriculture Bidhan Chandra Krishi Viswavidyalaya, PO - Krishi Viswavidyalaya, Mohanpur, Nadia, West Bengal, India

\section{Rajesh Khan}

Department of Agronomy, Faculty of Agriculture Bidhan Chandra Krishi Viswavidyalaya, PO - Krishi Viswavidyalaya, Mohanpur, Nadia, West Bengal, India

Sunil Kumar Gunri Department of Agronomy, Faculty of Agriculture Bidhan Chandra Krishi Viswavidyalaya, PO - Krishi Viswavidyalaya, Mohanpur, Nadia, West Bengal, India

Himangshu Das Assistant Professor in Agronomy, OUAT, Bhubaneswar, Odisha, India

Corresponding Author: Saumi Goswami Department of Agronomy, Faculty of Agriculture Bidhan Chandra Krishi Viswavidyalaya, PO - Krishi Viswavidyalaya, Mohanpur, Nadia, West Bengal, India

\section{Effect of 2, 4-D Ethyl Ester 80\% EC to control weeds in Wheat and its residual effect on succeeding crop Blackgram}

\author{
Saumi Goswami, Champak Kumar Kundu, Soumyajyoti Das, Rajesh \\ Khan, Sunil Kumar Gunri and Himangshu Das
}

DOI: $\underline{\text { https://doi.org/10.22271/chemi.2020.v8.i5k.10395 }}$

\section{Abstract}

The experiment was conducted during Rabi season of 2013-14 and summer season of 2014 at RRS, New Alluvial Zone, Chakdaha, BCKV, WB to disclose the bio-efficacy and phytotoxicity of 2,4-D Ethyl Ester $80 \%$ EC in wheat and its effect on succeeding crop blackgram. The field trial consisting of eight different treatments and laid out in randomized block design with three replications. Application of 2,4-D EE 80\% EC $0.90 \mathrm{~kg}$ a.i. ha-1 and 2, 4-D EE $80 \%$ EC $0.675 \mathrm{~kg}^{-1 . i .} \mathrm{ha}^{-1}$ have resulted in effective weed control, and contributed in significantly high grain yield of wheat and no phytotoxicity through these said treatments which were statistically comparable to hand weeding twice. 2, 4-D EE 80\% EC applied on wheat with different doses have found no residual effect on germination and yield of succeeding blackgram crop. So, these treatments can be a good option for wheat and succeeding black gram under sub-humid and subtropical condition of West Bengal.

Keywords: Bio-efficacy, black gram, phytotoxicity, wheat, 2, 4-D Ethyl Ester

\section{Introduction}

High population density and increasing food demand trigger the necessity of balanced food production by maintaining proper quantity and quality. Among the major food grains, wheat (Triticum aestivum L.) is one of the most important food crops of world playing vital role in global food security by providing adequate nutrition. India is the second largest producer of wheat, contributing $12 \%$ of the global production. Wheat production reached to 102.19 million tonnes with an approximate national productivity of 3,371 kg ha-1 during 2019 (Director's Report 2019, IIWBR, Karnal) ${ }^{[4]}$. Besides wheat, a significant cereal crop, pulses have taken place as a source of supplementary protein to daily diets for a predominantly vegetarian population and for those who cannot afford expensive animal protein. Blackgram (Vigna mungo L.) is an important highly priced and phosphoric acid rich pulse crop grown in India. Currently, India represents the largest producer (3560 Thousand Tonnes, Directorate of Economics and Statistics, 2017-18) ${ }^{[3]}$ of blackgram accounting for more than $70 \%$ of the global production. Amongst different factors which adversely impact the productivity of crops like wheat and black gram, weed infestation is the most harmful one but less noticeable. Weeds are one of the major constraints of low productivity of Urdbean during kharif season. For wheat, weeds can incur a grain yield loss of $48 \%$ (Khan and Haq, 2002) ${ }^{[5]}$. However, the extent of weed-related losses depends on the type and density of a particular weed species, its time of emergence, and the duration of the interference. Blackgram also is not a very good competitor against weeds (Choudhary et al. 2012) ${ }^{[2]}$, in general, yield loss due to uncontrolled weed growth in blackgram ranges from 27 to $100 \%$ (Singh and Singh, 2010) ${ }^{[8]}$. Weed causes severe damage at the different growth stages of crop. Weeds compete with wheat as well as with blackgram for nutrients, water, moisture \& light and ultimately drastically reduce crop yield. Hence, control measures should be taken judiciously for the weeds of crop growing areas for obtaining maximum returns. Manual weeding is the common practice to control weeds in both the crops (Chand et al. 2004) ${ }^{[1]}$. However, due to laborious, time consuming, costly and tiresome process makes the manual weeding impracticable. Furthermore, sudden weather abnormalities do not permit timely hand weeding. Thus, use of herbicides offer an 
alternative for effective control of weeds. Hence, there is need for some effective herbicide which can provide broad spectrum weed control in wheat field without affecting the present as well as succeeding crop growth and yield. 2, 4Dichlorophenoxy acetic acid (2,4-D) is selective as well as systemic and effective against broad-leaved plants/weeds and some sedges to some extent and that is absorbed through foliage and roots and is translocated to actively growing areas within the plant. Here, the present experiment was conducted to test the bio efficacy and phytotoxicity of this herbicide molecule used in wheat field for weed management and its effect on following crop blackgram.

\section{Materials and Methods}

The field trial was conducted to evaluate the bio-efficacy and phytotoxicity of 2, 4-D Ethyl Ester 80\% EC in Wheat during winter 2013-14 and its effect on succeeding crop Black gram during summer season of 2014at Regional Research Station, New Alluvial Zone, Chakdaha under Bidhan Chandra Krishi Viswavidyalaya, Mohanpur, Nadia, West Bengal. Farm is situated at $23^{0} 7^{\prime} \mathrm{N}$ latitude, 88052' E longitude, and $9.75 \mathrm{~m}$ above mean sea level. The topography of the land was referred as medium land situation. Soil at the experimental site $(0-15 \mathrm{~cm}$ depth) was loamy in texture containing $52.65 \%$ sand, $26.2 \%$ silt and $21.15 \%$ clay with $6.54 \mathrm{pH}$ and $0.57 \%$ organic carbon (OC). Available $\mathrm{N}, \mathrm{P}_{2} \mathrm{O}_{5}$ and $\mathrm{K}_{2} \mathrm{O}$ contents were 194.6, 47.2 and $198.2 \mathrm{~kg} / \mathrm{ha}$, respectively. The experimental plots were laid out in a randomized block design with three replications. There were eight different weed control treatments consisting of four different doses of 2,4-D Ethyl Ester 80\% EC (Nufarm) applied at 0.225, 0.450, 0.675, and $0.900 \mathrm{~kg}$ a.i. $\mathrm{ha}^{-1}$, 2,4-D Ethyl Ester 38\% EC (Commercial) with dose $0.450 \mathrm{~kg}$ a.i. ha $^{-1}$, metsulfuron methyl 20\% WP with dose of $0.004 \mathrm{~kg}$ a.i. ha ${ }^{-1}$, twice hand weeding at 20 days after sowing and 40 days after sowing, check as unweeded control. For phytotoxicity observation 2,4-D Ethyl Ester 80\% EC (Nufarm) was applied at $1.8000 \mathrm{~kg}$ a.i. ha ${ }^{-1}$. The herbicide solutions were sprayed uniformly in the experimental plots as per treatments and spraying was done with the help of hand operated knapsack sprayer fitted with a flat fan hooded nozzle with the spray volume of water $500 \mathrm{l} \mathrm{ha}^{-1}$. Data were recorded on weed population and dry weight of weeds. Total weed population was measured as the number of weeds per unit area at 20, 40 and 60 days after sowing from the quadrates according to the weed species in situ. For taking weed dry matter, the destructed weed samples were first washed in clean tap water, then sun-dried and hotair oven-dried for 48 hours at $70^{\circ} \mathrm{C}$ and weighed. Along with these, weed control efficiency was also measured.

Weed Control Efficiency $(\%), \mathrm{WCE}=\left(\left(\mathrm{WDM}_{\mathrm{C}}-\mathrm{WDM}_{\mathrm{t}}\right) /\right.$ $\left.\mathrm{WDM}_{\mathrm{c}}\right) \times 100$

where, $\mathrm{WDM}_{\mathrm{c}}=$ Weed dry weight in control plot \& $\mathrm{WDM}_{\mathrm{t}}=$ Weed dry weight in treated plot. Phytotoxic effect of herbicides on crop in terms of yellowing, stunting and necrosis were recorded at 7,14 and 21 days after herbicide application (DAHA).Succeeding crop black gram was taken during summer season of 2014 to find out the residual effects of herbicides 2, 4-D ethyl ester 80\% EC, 2, 4-D ethyl ester 38\% EC and Metsulfuron Methyl 20\% WP. Blackgram variety 'Kalindi' (B-76) was sown in rows $25 \mathrm{~cm}$ apart (individual plot size was $5 \mathrm{~m}$ x $4 \mathrm{~m}$ ) using $25 \mathrm{~kg}$ seeds ha- ${ }^{-1}$ on $23^{\text {rd }}$ March, 2014. These studies were continued in fixed lay out without disturbing the soil. The weeds were removed manually in these crops. Observations on germination percent at 10 DAS (days after sowing) of the succeeding black gram crop was recorded during the experiment. The total yield of succeeding crop was recorded at the time of harvest.

\section{Result and Discussion \\ Effect on Weed Population}

The experimental field was heavily infested with different types of weed flora in all the individual plots. Data obtained from (Table-1) recorded significant reduction in total weed population for the herbicide treatments. Application of 2, 4-D EE $80 \%$ EC of $0.90 \mathrm{~kg}$ a.i. ha ${ }^{-1}$ has resulted in effective control of total weeds and has recorded least weed count at 20, 40 and 60 DAS and superior to the other treatments except hand weeding twice where weed density was minimized to a great extent. From the table, it is also clear that in controlling total weed population 2, 4-D EE $80 \%$ EC of $0.90 \mathrm{~kg}^{\text {a.i. }}$ ha ${ }^{-1}$ was at par with 2,4-D EE $80 \%$ EC of $0.675 \mathrm{~kg}$ a.i. ha-1. The unweeded control treatment recorded the maximum weed count (Table-1) at all the observations. Therefore, data regarding total weed population exhibited that application of 2, 4-D EE $80 \%$ EC $0.90 \mathrm{~kg}$ a.i. ha-1 was proved most effective followed by 2, 4-D EE $80 \%$ EC of $0.675 \mathrm{~kg}^{\text {a.i. }} \mathrm{ha}^{-1}$ in controlling severe weed density in wheat field. The results are in conformity with the research findings of Kundu et al. $2018^{[6]}$ where it was revealed that all types of weeds have controlled by 2, 4-D ethyl ester $80 \%$ EC $3.6 \mathrm{~kg}^{\text {a.i. }} \mathrm{ha}^{-1}$ and has recorded least weed population at 20, 40 and 60 DAS and remained at par among themselves and superior to the other treatments except hand weeding.

\section{Effect on Weed Dry Matter Production and Weed Control Efficiency}

Weed biomass production was recorded similarly at 20, 40 and 60 DAS and the data of which are recorded in Table 1. Observations in the table on weed dry matter production exhibited that the biomass of the weed species also differed significantly between herbicide treatment with 2,4-D EE $80 \%$ EC of $0.90 \mathrm{~kg}$ a.i. ha-1 followed by 2,4-D EE $80 \%$ EC of $0.675 \mathrm{~kg}$ a.i. ha ${ }^{-1}$ except for twice hand weeding at 20 and 40 DAS in which weed biomass production were recorded lowest among all the treatments that followed a trend like that of weed density. The weed dry weight in the aforementioned treatments remained at par among themselves and also remain significantly superior to the other treatments at all the stages especially that of the standard treatments viz., 2,4-D EE 80\% EC $0.225 \mathrm{~kg}$ a.i. ha ${ }^{-1} 2,4-$ D EE $80 \%$ EC (Nufarm) $0.45 \mathrm{~kg}$ a.i. ha $^{-1}, 2,4-D$ EE $38 \%$ EC(Commercial) $0.45 \mathrm{~kg}$ a.i. ha ${ }^{-1}$ and Metsulfuron methyl 20\% WP $0.004 \mathrm{~kg}$ a.i. ha-1.

Another important measure of weed management is weed control efficiency which is derived from weed biomass production and the data are arranged in Table 1 . From this table it is evident that among all the treatment combinations, the maximum value of weed control efficiency was achieved for hand weeding twice at 20 and 40 DAS. This was followed by 2, 4-D EE $80 \%$ EC $0.90 \mathrm{~kg}$ a.i. ha-1 and 2, 4-D EE 80\% EC $0.675 \mathrm{~kg}$ a.i. ha- ${ }^{-1}$. Therefore, it can be said that except two hand weeding, higher but judicious application of 2, 4-D EE $80 \%$ EC is effective for obtaining higher weed control efficiency. More the dose of 2,4-D EE 80\% EC greater was the weed control efficiency (WCE). Researchers and scientists in different years have also proven that WCE reflects the effectiveness of applied weed management treatments in securing yield against weed competition.

\section{Phytotoxicity}

The observation on visual crop toxicity was done on 7, 14 and 21 days after herbicide application (DAHA). Phytotoxicity 
level was measured by visual assessment based on Phytotoxicity Rating Scale (PRS) 0 to 10 , where $0=$ No crop injury while $10=$ Heavy injury or complete destruction of test crop. The visual crop toxicity symptoms like leaf injury, vein clearing, epinasty, hyponasty, scorching and necrosis were observed to some extent. Herbicide residual effect was not observed in any of the herbicide treatments with different doses. It is also distinct from Table 1 . that no crop phytotoxicity symptoms were traced even at the highest dose of 2,4-D EE $80 \%$ EC $0.90 \mathrm{~kg}$ a.i. ha ${ }^{-1}$.The result can be confirmed by the research findings of Mundra and Maliwal in $2012^{[7]}$ where he recorded no phytotoxic effects on blackgram in terms of epinasty, hyponasty, necrosis, vein clearing and wilting at 3, 5, 7 and 15 days after application of quizalofopethyl@ 37.5 g/ha and thus, found completely safe for the crop.

\section{Residual Effect of Herbicides on Succeeding Crop Black gram}

The results regarding germination percentage and yield of succeeding crop black gram are presented in Table 2 which revealed that the germination percent of succeeding crop at 10
DAS remain slightly affected irrespective of the treatments. This suggests that best germination obtained in hand weeding twice $\left(\mathrm{T}_{7}\right)$ plot $(74.00 \%)$ followed by 2,4-D EE 80\% EC $0.450 \mathrm{~kg}$ a.i. ha-1 $\left(\mathrm{T}_{2}\right)(72.00 \%), 2,4-\mathrm{D}$ EE $80 \%$ EC $0.675 \mathrm{~kg}$ a.i. ha ${ }^{-1}\left(\mathrm{~T}_{3}\right)(72.00 \%)$ and 2,4-D EE $80 \%$ EC $0.900 \mathrm{~kg}$ a.i. ha${ }^{1}\left(\mathrm{~T}_{4}\right)(71.50 \%)$ treatments. Similar trend follows in case of yield also where except two hand weeding treatment (6.93 q $\mathrm{ha}^{-1}$ ), application of 2,4-D EE $80 \%$ EC $0.450 \mathrm{~kg}$ a.i. ha-1 i.e. $\mathrm{T}_{2}$ recorded maximum yield $\left(5.90 \mathrm{q} \mathrm{ha}^{-1}\right)$ which is statistically at par with application of 2,4-D EE $80 \%$ EC $0.675 \mathrm{~kg}$ a.i. ha ${ }^{-1}$ $\left(\mathrm{T}_{3}\right)\left(5.85 \mathrm{q} \mathrm{ha}^{-1}\right)$. The treatment $\mathrm{T}_{4}$ exhibited also satisfactory result regarding yield (5.80 q ha-1).Yield of succeeding black gram showed no distinct variation due to the application of herbicide at varying doses in every experiment for controlling weeds in wheat.

\section{Correlation Analysis}

The correlation analysis between weed density, and weed dry weight with the germination percentage and yield of succeeding crop black gram is presented in Table 3. The weed density and dry matter had negative correlation with the yield of black gram.

Table 1: Effect of different treatments on weed population, weed dry matter, Weed Control Efficiency (WCE) and phytotoxicity in wheat

\begin{tabular}{|c|c|c|c|c|c|c|c|c|c|c|c|c|c|c|}
\hline \multirow{2}{*}{$\begin{array}{l}\text { Tr. } \\
\text { No. }\end{array}$} & \multirow{2}{*}{ Treatment } & \multirow[t]{2}{*}{ Dose a.i. $\mathrm{kg} \mathrm{ha}^{-1}$} & \multicolumn{3}{|c|}{$\begin{array}{c}\text { Total weed } \\
\text { Population }\left(\text { No. }^{-2}\right) \\
\end{array}$} & \multicolumn{3}{|c|}{$\begin{array}{c}\text { Weed dry matter production } \\
\left(\mathrm{g} \mathrm{m}^{-2}\right)\end{array}$} & \multicolumn{3}{|c|}{$\begin{array}{r}\text { Weed control } \\
\text { efficiency (\%) }\end{array}$} & \multicolumn{3}{|c|}{$\begin{array}{c}\text { Phytotoxicity } \\
\text { observation }\end{array}$} \\
\hline & & & 20 DAS & $\begin{array}{c}40 \\
\text { DAS }\end{array}$ & \begin{tabular}{|c|}
60 \\
DAS \\
\end{tabular} & 20 DAS & 40 DAS & 60 DAS & \begin{tabular}{|c|}
20 \\
DAS \\
\end{tabular} & \begin{tabular}{|c|}
40 \\
DAS \\
\end{tabular} & \begin{tabular}{|c|}
60 \\
DAS \\
\end{tabular} & $\begin{array}{c}7 \\
\text { DAHA } \\
\end{array}$ & \begin{tabular}{|c|}
14 \\
DAHA \\
\end{tabular} & \begin{tabular}{|c|}
21 \\
DAHA \\
\end{tabular} \\
\hline $\mathrm{T}_{1}$ & $\begin{array}{l}\text { 2, 4-D EE 80\% EC } \\
\text { (Nufarm) }\end{array}$ & 0.225 & 2.98 & 4.91 & 5.20 & 1.21 & 2.56 & 2.98 & 83.47 & \begin{tabular}{|l|l}
68.47 \\
\end{tabular} & 58.26 & 0 & 0 & 0 \\
\hline $\mathrm{T}_{2}$ & $\begin{array}{l}\text { 2, 4-D EE 80\% EC } \\
\text { (Nufarm) }\end{array}$ & 0.450 & 2.50 & 4.12 & 4.90 & 1.09 & 1.78 & 2.52 & 85.11 & 78.08 & 64.71 & 0 & 0 & 0 \\
\hline $\mathrm{T}_{3}$ & $\begin{array}{c}\text { 2, 4-D EE 80\% EC } \\
\text { (Nufarm) }\end{array}$ & 0.675 & 2.20 & 3.70 & 4.55 & 1.05 & 1.49 & 2.40 & 85.66 & 81.65 & 66.39 & 0 & 0 & 0 \\
\hline $\mathrm{T}_{4}$ & $\begin{array}{l}\text { 2, 4-D EE 80\% EC } \\
\text { (Nufarm) }\end{array}$ & 0.900 & 2.00 & 3.12 & 4.40 & 1.00 & 1.39 & 2.11 & 86.34 & 82.88 & 70.45 & 0 & 0 & 0 \\
\hline $\mathrm{T}_{5}$ & $\begin{array}{l}\text { 2, 4-D EE 38\% EC } \\
\text { (Commercial) }\end{array}$ & 0.450 & 2.85 & 4.51 & 5.12 & 1.16 & 2.00 & 2.67 & 84.15 & 75.37 & 62.61 & 0 & 0 & 0 \\
\hline $\mathrm{T}_{6}$ & $\begin{array}{l}\text { Metsulfuron methyl } \\
20 \% \text { WP }\end{array}$ & 0.004 & 2.94 & 4.78 & 5.14 & 1.20 & 2.11 & 2.79 & 83.61 & 74.01 & 60.92 & 0 & 0 & 0 \\
\hline $\mathrm{T}_{7}$ & Hand weeding twice & - & 1.21 & 1.51 & 1.97 & 0.67 & 0.85 & 1.02 & 90.85 & 89.53 & 85.71 & 0 & 0 & 0 \\
\hline $\mathrm{T}_{8}$ & Unweeded control & - & 10.15 & 14.13 & 16.29 & 7.32 & 8.12 & 7.14 & 0.00 & 0.00 & 0.00 & 0 & 0 & 0 \\
\hline & $\begin{array}{c}\mathrm{SE}(\mathrm{d}) \\
\mathrm{CD}(\mathrm{P}=0.05)\end{array}$ & & $\begin{array}{l}0.31 \\
0.87\end{array}$ & $\begin{array}{l}0.56 \\
1.58\end{array}$ & $\begin{array}{l}0.75 \\
2.15\end{array}$ & $\begin{array}{l}0.19 \\
0.48\end{array}$ & $\begin{array}{l}0.31 \\
0.86\end{array}$ & $\begin{array}{l}0.37 \\
1.01\end{array}$ & & & & - & - & - \\
\hline
\end{tabular}

Table-2: Residual effect of different herbicides applied in wheat on succeeding black gram crop

\begin{tabular}{|c|c|c|c|c|}
\hline Tr. No. & Treatments & Dose a.i. kg/ha & Germination (\%) & Yield (q ha ${ }^{-\mathbf{1}}$ ) \\
\hline $\mathrm{T}_{1}$ & 2, 4-D EE 80\% EC (Nufarm) & 0.225 & 68.00 & 5.20 \\
\hline $\mathrm{T}_{2}$ & 2, 4-D EE 80\% EC (Nufarm) & 0.450 & 72.00 & 5.90 \\
\hline $\mathrm{T}_{3}$ & 2, 4-D EE 80\% EC (Nufarm) & 0.675 & 72.00 & 5.85 \\
\hline $\mathrm{T}_{4}$ & 2, 4-D EE 80\% EC (Nufarm) & 0.90 & 71.50 & 5.80 \\
\hline $\mathrm{T}_{5}$ & 2, 4-D EE 38\% EC (Commercial) & 0.45 & 70.50 & 5.66 \\
\hline $\mathrm{T}_{6}$ & Metsulfuron methyl 20\% WP & 0.004 & 70.00 & 5.52 \\
\hline $\mathrm{T}_{7}$ & Hand weeding twice & - & 74.00 & 6.93 \\
\hline $\mathrm{T}_{8}$ & Unweeded control & & 67.00 & 5.00 \\
\hline & SE (d) & & 10.41 & NS \\
\hline
\end{tabular}

Table 3: Pearson's correlation matrix among the weed density, dry weight at 60 days after sowing and Germination \% and yield of succeeding crop

\begin{tabular}{|c|c|c|c|c|}
\hline Parameters & Weed density $\left(\mathbf{n o} . \mathbf{m}^{2}\right)$ & Weed dry weight $\mathbf{( g / \mathbf { m } ^ { 2 } )}$ & Germination (\%) & Seed yield (q/ha) \\
\hline Weed density $\left(\mathrm{no} . \mathrm{m}^{2}\right)$ & 1 & 1 & & \\
\hline Weed dry weight $\left(\mathrm{g} / \mathrm{m}^{2}\right)$ & $0.994^{* *}$ & $-0.828^{*}$ & 1 & \\
\hline Germination \% & $-0.771^{*}$ & $-0.760^{* *}$ & $0.939^{* *}$ & 1 \\
\hline Seed yield (q/ha) & $-0.695^{\mathrm{NS}}$ & & & \\
\hline
\end{tabular}




\section{Conclusion}

The present investigation conclusively inferred that except for twice hand weeing treatment $\left(\mathrm{T}_{7}\right), 2$, 4-D EE $80 \%$ EC 0.450 kg a.i. ha ${ }^{-1}\left(\mathrm{~T}_{2}\right)$ and 2, 4-D EE $80 \%$ EC $0.675 \mathrm{~kg}$ a.i. ha ${ }^{-1}\left(\mathrm{~T}_{3}\right)$ applied in wheat during 2013 on the succeeding crop revealed that there is better impact on either the germination (\%) or yield of black gram crop compare to the other herbicidal doses grown during 2014. Hence it can be concluded that the aforesaid treatment of this experiment applied in wheat during 2013 is best for succeeding crop black gram.

\section{References}

1. Chand R, Singh NP, Singh VK. Effect of weed control treatments on weeds and grain yield of late planted urdbean during kharif season. Indian J. Pulses Res. 2004; 16:163-64.

2. Choudhary VK, Kumar PS, Bhagawati R. Integrated weed management in blackgram (Vigna mungo) under mid hills of Arunachal Pradesh. Indian Journal of Agronomy. 2012; 57(4):382-385.

3. Commodity profile for Pulses, Annual Report. Directorate of Economics and Statistics, 2019, 2017-18

4. Director's Report (ICAR) 2019. Progress Report (All India Coordinated Research Project) (AICRP) on Wheat and Barley, 2019.

5. Khan M, Haq N. Wheat crop yield loss assessment due to weeds. Sarhad J. Agric. 2002; 18:443-457.

6. Kundu CK, Biswas U, Kundu A, Khan R, Lamana MCL. Studies on bio-efficacy of 2, 4-D Ethyl Ester 80\% EC in maize and its effect on succeeding crop lentil. J. of Pharmacogn. and Phytochem. 2018; SP1:1514-1517.

7. Mundra SL, Maliwal PL. Influence of quizalofop-ethyl on narrow-leaved weeds in blackgram and its residual effect on succeeding crops. Indian Journal of Weed Science. 2012; 44(4):231-234.

8. Singh M, Singh RP. Influence of crop establishment methods and weed management practices on yield and economics of direct seeded rice (Oryza sativa). Indian Journal of Agronomy. 2010; 55:224-29. 